\title{
Impact of Motivation on Employees
}

\author{
V. Manimozhi ${ }^{1}$, D. Supulakshmi M.Com., M.phil., S.E.T. ${ }^{2}$ \\ ${ }^{1}$ M. Phil Research Scholar, S.T.E.T. Women's College, Mannargudi \\ ${ }^{2}$ Research Advisor, Assistant Professor of Commerce, S.T.E.T Women’s College, Mannargudi
}

\begin{abstract}
Motivation ensures best and efficient utilization of all types of resources. All other resources i.e., materials and machines can produce no results unless human resources put them into action. Will to contribute there is a difference between "capacity to work" and "willingness to work". A man can be physically and mentally fit to work but he may not be willing to work. The researcher analyze the data from the questionnaire, $51 \%$ of respondents feel that there is a relationship between their job and their education. $75 \%$ of workers are satisfied with the working hours.85\% of the respondents have a satisfaction that they have a good relationship with their job satisfaction. He suggested that the Employees are convenient with their working schedule The firm should keep the existing physical work environment is comfortable.
\end{abstract}

Keywords: motivation, workers, relationship and employees

\section{Introduction}

Motivation is a term which implies that one person induces another, to engage in action by ensuring that a channel to satisfy the motive becomes available and accessible to the individual. In addition to channelizing the strong motives in a direction that is satisfying to both the organization and the employees. The manager can also activate the latent motives in individuals and largess them in a manner that would be functional for the organization.

\section{Importance of Motivation}

Best Utilization of resources: Motivation ensures best and efficient utilisation of all types of resources. All other resources i.e., materials and machines can produce no results unless human resources put them into action. Will to contribute: There is a difference between "capacity to work" and "willingness to work". A man can be physically and mentally fit to work but he may not be willing to work.

\section{Objectives}

- To analyze the motivational level of employees.

- To find the satisfaction level of promotion system.

- To study the satisfaction level of grievances handling procedure.

\section{Research Methodology}

Research methodology is the rearrangement it conditions for collection and analysis of data in a manner that aims to refer the research purpose with economy in procedure.

\section{Research Design:}

The research design adopted in this study is descriptive research.

\section{Problem of the Study}

To know or identify employees Motivation on Prime Overseas Garments (P) Ltd, Tiruppur.

\section{Source of Data}

\section{(i) Primary data}

It is also named as firsthand information. The researcher has used primary data for collecting information and the researchers has used questionnaire as a tool for collection.

\section{(ii) Secondary data}

Secondary data refers to those that are collected from the Organization Books, Internet, Publications, Journals and Magazines.

The researcher collect the information through questionnaire and analyse the following particulars.

Table 1: Designation of the Respondents

\begin{tabular}{|c|l|c|c|}
\hline S. No. & Designation & No. of Respondents & Percentage (\%) \\
\hline 1 & Worker & 63 & 60 \\
\hline 2 & Supervisor & 10 & 10 \\
\hline 3 & Assistant Manager & 08 & 08 \\
\hline 4 & Managers & 03 & 02 \\
\hline 5 & Others & 21 & 20 \\
\hline & Total & $\mathbf{1 0 5}$ & $\mathbf{1 0 0}$ \\
\hline
\end{tabular}

Source: Primary Data.

\section{Inference}

The above table shows that 60 percent of the respondents are workers, 20 percent of the respondents are other categories, 10 percent of the respondents are supervisor, 8 percent of the respondents are Assistant managers and only 2 percent of the respondents are manager categories. 


\section{International Journal of Science and Research (IJSR) \\ ISSN (Online): 2319-7064}

Index Copernicus Value (2013): 6.14 | Impact Factor (2014): 5.611

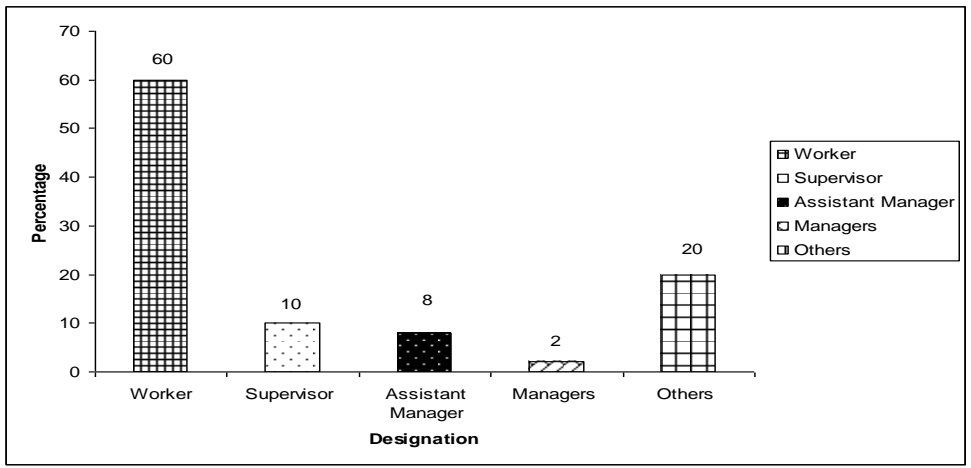

Chart 1: Designation of the Respondents

Table 2: Classification of the Respondents on the Basis of Experience

\begin{tabular}{|c|l|c|c|}
\hline S. No & Experience & No. of Respondents & Percentage (\%) \\
\hline 1 & Below 1 year & 10 & 09 \\
\hline 2 & $1-3$ years & 20 & 19 \\
\hline 3 & $3-5$ years & 36 & 35 \\
\hline 4 & $5-7$ years & 28 & 27 \\
\hline 5 & Above 7 years & 11 & 10 \\
\hline & Total & $\mathbf{1 0 5}$ & $\mathbf{1 0 0}$ \\
\hline
\end{tabular}

Source: primary data

\section{Inference}

It is inferred from the above table that $35 \%$ of the respondents have the experience of 3-5 years and $9 \%$ of the respondents have the experience of below 1 year.

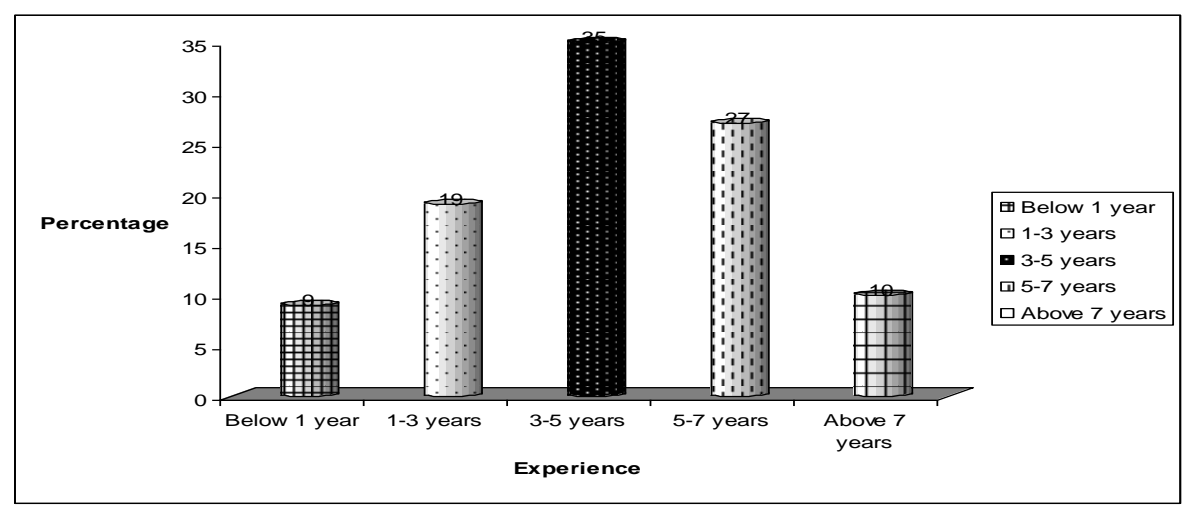

Chart 2: Classification of the Respondents on the Basis of Experience

Table 3: Classification of the Respondents on the Basis of Satisfaction on Incentives

\begin{tabular}{|c|c|c|}
\hline Feel about facilities & No. of Respondents & Percentage (\%) \\
\hline Highly Satisfied & 35 & 33 \\
\hline Satisfied & 45 & 43 \\
\hline Neutral & 21 & 20 \\
\hline Dissatisfied & 04 & 04 \\
\hline Highly Dissatisfied & -- & -- \\
\hline Total & $\mathbf{1 0 5}$ & $\mathbf{1 0 0}$ \\
\hline
\end{tabular}

\section{Inference}

The above table shows that the basis of satisfaction of incentives provided to the respondents, $43 \%$ of the respondents are satisfied and $4 \%$ of the respondents are dissatisfied.

Source: Primary Data

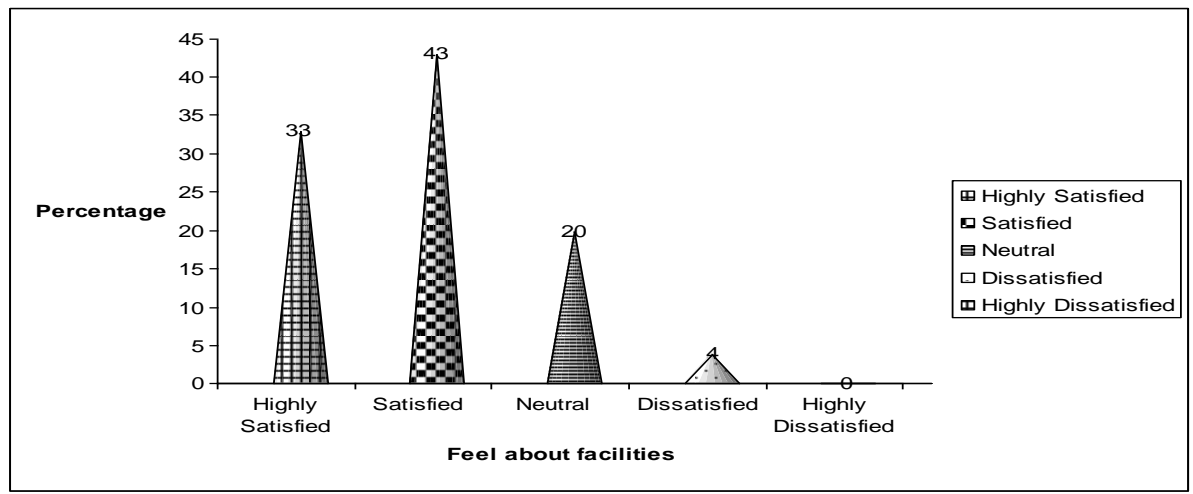

Chart 3: Classification of the Respondents on the Basis of Satisfaction on Incentives

Volume 5 Issue 2, February 2016 


\section{International Journal of Science and Research (IJSR) \\ ISSN (Online): 2319-7064}

Index Copernicus Value (2013): 6.14 | Impact Factor (2014): 5.611

Table 4: Classification of the Respondents on the Basis of Satisfaction Level of Motivation Programme

\begin{tabular}{|c|c|c|}
\hline Feel about facilities & No. of Respondents & Percentage (\%) \\
\hline Highly Satisfied & 25 & 24 \\
\hline Satisfied & 42 & 40 \\
\hline Neutral & 35 & 33 \\
\hline Dissatisfied & 03 & 03 \\
\hline Highly Dissatisfied & --- & --- \\
\hline Total & 105 & 100 \\
\hline
\end{tabular}

\section{Inference}

The table shows the satisfaction of motivation by the company to the employees $40 \%$ are satisfied and $03 \%$ are respondent dissatisfied.

Source: Primary Data

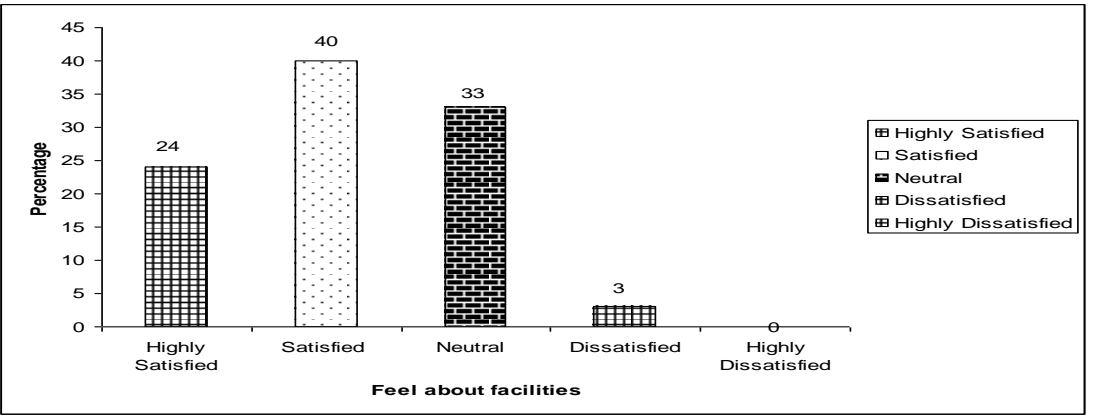

Chart 4: Classification of the Respondents on the Basis of Satisfaction Level of Motivation Programme

Table 5: Classification of the Respondents on the Basis of Satisfaction of Present Promotion Policy

\begin{tabular}{|c|c|c|}
\hline Opinion & No. of Respondents & Percentage (\%) \\
\hline Highly Satisfied & 07 & 07 \\
\hline Satisfied & 42 & 40 \\
\hline Neutral & 50 & 48 \\
\hline Dissatisfied & 4 & 4 \\
\hline Highly Dissatisfied & 2 & 2 \\
\hline Total & 105 & 100 \\
\hline
\end{tabular}

Source: Primary Data

\section{Inference}

The table shows that the present promotional policy of the respondents, $48 \%$ of the respondents are neither satisfied nor dissatisfied and $2 \%$ of the respondents are highly dissatisfied.

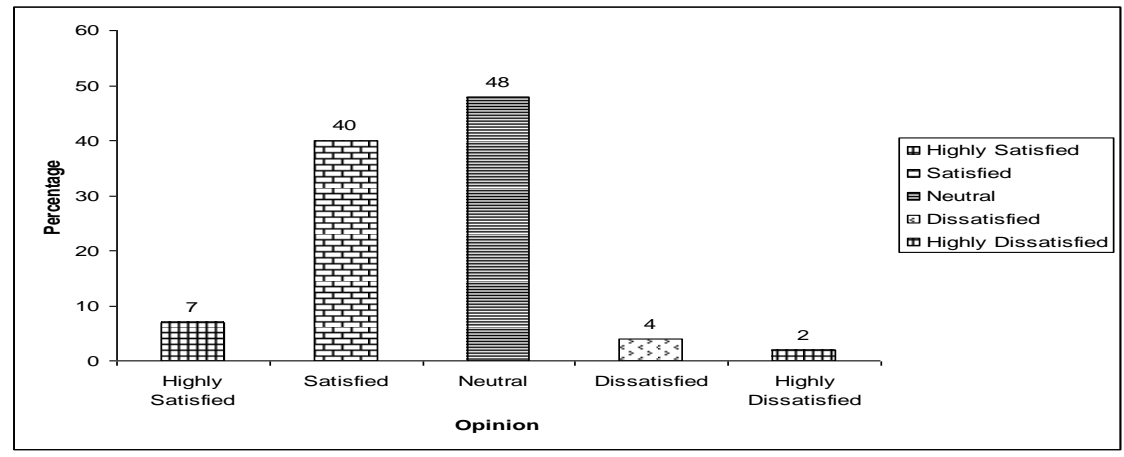

Chart 5: Classification of the Respondents on the Basis of Satisfaction of Present Promotion Policy

\section{Findings}

1) Present income has created a satisfaction among $72 \%$ of respondents.

2) $51 \%$ of respondents feel that there is a relationship between their job and their education.

3) $75 \%$ of workers are satisfied with the working hours.

4) $85 \%$ of the respondents have a satisfaction that they have a good relationship with their job satisfaction.

5) $43 \%$ of the respondents are satisfied, $33 \%$ of the respondents are highly satisfied about their incentives.

6) The satisfaction of motivation by the company to the employees are $40 \%, 33 \%$ are neither satisfied nor dissatisfied.

\section{Suggestions}

1) The firm should concentrate employees stress counseling services

2) Employees should freely express their feelings at their working time and personal life

3) The firm should concentrate on medical department, it should satisfy their each employees

4) The company should concentrate each level of employees in order to know their entertaining programme benefited to the employees.

5) Employees are convenient with their working schedule

6) The firm should keep the existing physical work environment is comfortable.

7) Improvement of quality should be considered but at the same time price equilibrium should be maintained.

\section{Volume 5 Issue 2, February 2016}




\section{International Journal of Science and Research (IJSR) \\ ISSN (Online): 2319-7064}

Index Copernicus Value (2013): 6.14 | Impact Factor (2014): 5.611

8) Better and improved action is influenced during sales.

9) Steps should be taken to make the products available in different quantities.

10) Sensible advertisement should be made for better impression in the customer mind.

11) The manufacturer must take market survey once in six months to know the consumer attitude and preference.

\section{Conclusion}

On the basis of the study made by the researcher, it is found that the employee motivation develop the employees as well as the organisation. The way that the motivation used to explain in the methods of motivation and effectiveness should be easy to understand so that their learning and involvement will increase the proper motivation will result in high productivity and reduction of wastage and industrial accident.

\section{References}

\section{Books}

[1] Tripathi. P.C. (2004), (Personnel Management), Sultan Chand \& Sons, New Delhi.

[2] Kannan, R (1999) "Human resource Development and Employment growth in India". The Indian Journal of Labor Economics, pp 15.

[3] Pareek, U, and Rao, T.V. Designing and Managing Human Resource System, Oxford \& IBH Publishing Company, 2001 New Delhi.

[4] Billimorid R.P. and Sing N.K. Human Resource Development, Vikas Publishing House, New Delhi.

[5] Kothari C.R. (1985), (Research Methodology), Wishwa Prakasan, New Delhi. 